\title{
Usefulness of serum procalcitonin levels in pulmonary tuberculosis
}

\author{
M. Ugajin*,,ף, S. Miwa*, M. Shirai*, H. Ohba*, T. Eifuku*, H. Nakamura* , T. Suda\#, \\ H. Hayakawa* and K. Chida ${ }^{\#}$
}

ABSTRACT: There are very few data on serum procalcitonin (PCT) levels in pulmonary tuberculosis (PTB) patients who are negative for HIV.

We assessed serum PCT in consecutive patients diagnosed with pulmonary tuberculosis or community-acquired pneumonia (CAP) on admission to discriminate between PTB and CAP, and examined the value of prognostic factors in PTB.

102 PTB patients, 62 CAP patients, and 34 healthy volunteers were enrolled. Serum PCT in PTB patients was significantly lower than in CAP patients (mean \pm SD $0.21 \pm 0.49$ versus $\left.4.10 \pm 8.68 \mathrm{ng} \cdot \mathrm{mL}^{-1} ; \mathbf{p}<0.0001\right)$. By receiver-operating characteristic curve analysis, serum PCT was an appropriate discrimination marker for PTB and CAP (area under the curve 0.866). PTB patients with $\geqslant 0.5 \mathrm{ng} \cdot \mathrm{mL}^{-1}$ (normal cut-off) had significantly shorter survival than those with $<0.5 \mathrm{ng} \cdot \mathrm{mL}^{-1}(\mathrm{p}<0.0001)$.

Serum PCT is not habitually elevated in HIV-negative PTB patients and is a useful biomarker for discriminating between PTB and CAP; however, when serum PCT is outside the normal range, it is a poor prognostic marker.

KEYWORDS: Procalcitonin, prognosis, pulmonary tuberculosis

rocalcitonin $(\mathrm{PCT})$, the precursor molecule of calcitonin, is known as a systemic inflammatory protein. Several studies have reported that serum PCT is a useful biomarker for diagnosis and for estimating the severity of community-acquired pneumonia (CAP) $[1,2]$. In particular, high serum PCT with CAP is associated with a high mortality rate [3-7]. In contrast to CAP, there are very few data on PCT levels in pulmonary tuberculosis (PTB). According to the limited information available from small scale studies, which included 27 PTB patients [8], 30 PTB patients [9], and 34 HIVpositive PTB patients [10], serum PCT was not elevated; however, the clinical significance of serum PCT levels in PTB patients has not been well documented. In this study, we examined serum PCT levels in HIV-negative PTB patients to discriminate between PTB and CAP. Moreover, we investigated whether serum PCT levels in PTB patients are related to disease prognosis.

\section{METHODS}

\section{Patients}

From June 2008 to September 2009, consecutive patients admitted to our hospital (Tenryu Hospital, Hamamatsu, Japan) with PTB or CAP were included in this study. PTB was defined by sputum smear-positive and culture-positive Mycobacterium tuberculosis in the presence of new radiographic pulmonary infiltration. According to the European consensus on the surveillance of tuberculosis [11], PTB patients with tuberculous involvement of other organ systems were defined as having disseminated tuberculosis. Patients with other infections, such as urinary tract infection, meningitis and infectious endocarditis, were excluded. All PTB patients were initially treated with a standard four-drug regimen of isoniazid, rifampin, pyrazinamide, and ethambutol or streptomycin.

Pneumonia was diagnosed by the presence of new radiographic pulmonary infiltration and the following clinical findings: 1) axillary temperature $>37.5^{\circ} \mathrm{C}$; and 2) a cough, purulent sputum, pleuritic chest pain or shortness of breath. CAP was defined if pneumonia had occurred at home without antibiotic use in the previous 14 days.

As the severity index, the Pneumonia Patients Outcome Research Team score [12] was used in all PTB and CAP patients. Healthy volunteers free from respiratory disease were included as normal controls.

This study was prospective and was approved by the ethics committee of our hospital, and informed consent was obtained according to the hospital's guidelines.
AFFILIATIONS

*Dept of Respiratory Medicine, Tenryu Hospital, National Hospital Organization,

${ }^{\text {\#}}$ Second Division, Dept of Internal Medicine, Hamamatsu University School of Medicine, Hamamatsu, Japan.

"Both authors contributed equally to this work.

CORRESPONDENCE

S. Miwa

4201-2 Oro

Hamakitaku

Hamamatsu

434-8511

Japan

E-mail: hirosei@za.tnc.ne.jp

Received:

Jan 232010

Accepted after revision:

May 242010

First published online:

June 072010 


\section{Methods}

Venous blood samples were drawn from PTB and CAP patients on admission. Serum PCT and C-reactive protein (CRP) were measured within $24 \mathrm{~h}$ of admission. Serum PCT was determined by an immunoluminometric assay (Sphere Light B.R.A.H.M.S PCT; Wako Diagnostics, Tokyo, Japan). The normal range of PCT is $<0.5 \mathrm{ng} \cdot \mathrm{mL}^{-1}$ and the lower limit of detection is $0.1 \mathrm{ng} \cdot \mathrm{mL}^{-1}[13,14]$. Serum CRP was determined by a turbidimetric assay (Nanopia CRP; Sekisui Medical, Tokyo, Japan). The lower limit of detection was $0.1 \mathrm{mg} \cdot \mathrm{dL}^{-1}$. White blood cell (WBC) and differential cell counts were determined by flow cytometry (XT-2000i; SYSMEX Corporation, Kobe, Japan). If serum PCT and CRP were lower than their detection limit, we defined them as $0.05 \mathrm{ng} \cdot \mathrm{mL}^{-1}$ and $0.05 \mathrm{mg} \cdot \mathrm{dL}^{-1}$, respectively.

\section{Statistical analysis}

Data are expressed as mean \pm SD. Differences between groups were tested using the nonparametric Mann-Whitney U-test for continuous variables and Fisher's exact test for categorical variables, respectively. PTB and CAP were discriminated using receiver-operating characteristic (ROC) analysis. Mortality within 60 days of admission was analysed by Kaplan-Meier survival curves and by the log-rank test, according to cut-off values of $10.00 \mathrm{mg} \cdot \mathrm{dL}^{-1}$ serum CRP $[15,16]$ and $0.5 \mathrm{ng} \cdot \mathrm{mL}^{-1}$ serum PCT [13, 14], respectively. A probability value of $<0.05$ was regarded as significant.

\begin{tabular}{|c|c|c|c|c|}
\hline & PTB & CAP & Control & $\mathrm{p}$-value \\
\hline \multicolumn{5}{|l|}{ Demographics } \\
\hline Patients n & 102 & 62 & 34 & \\
\hline Age yrs & $71.5 \pm 18.5$ & $75.2 \pm 17.0$ & $64.7 \pm 15.3$ & 0.2194 \\
\hline Males/females $n$ & $63 / 39$ & $38 / 24$ & $11 / 23$ & $>0.9999$ \\
\hline \multicolumn{5}{|l|}{ Symptoms } \\
\hline Fever & $48(47.1)$ & $62(100)$ & & $<0.0001$ \\
\hline Cough or sputum & $53(52.0)$ & $44(71.0)$ & & 0.0216 \\
\hline Dyspnoea & $22(21.6)$ & $38(61.3)$ & & $<0.0001$ \\
\hline Chest pain & $4(3.9)$ & $5(8.1)$ & & 0.3005 \\
\hline Weight loss & $19(18.6)$ & $2(3.2)$ & & 0.0035 \\
\hline \multicolumn{5}{|l|}{ Laboratory test } \\
\hline PCT $n g \cdot \mathrm{mL}^{-1}$ & $0.21 \pm 0.49$ & $4.10 \pm 8.68$ & $0.05 \pm 0$ & $<0.0001$ \\
\hline $\mathrm{CRP} \mathrm{mg} \cdot \mathrm{dL}^{-1}$ & $6.18 \pm 5.75$ & $15.67 \pm 9.59$ & $0.14 \pm 0.27$ & $<0.0001$ \\
\hline WBC $10^{9}$ cells $\cdot L^{-1}$ & $7.87 \pm 3.12$ & $13.01 \pm 8.23$ & $5.95 \pm 1.33$ & $<0.0001$ \\
\hline Neutrophils $10^{9}$ cells $\cdot \mathrm{L}^{-1}$ & $6.23 \pm 3.10$ & $11.57 \pm 8.20$ & $3.62 \pm 1.43$ & $<0.0001$ \\
\hline Lymphocytes $10^{9}$ cells $\cdot L^{-1}$ & $1.04 \pm 0.73$ & $1.02 \pm 0.55$ & $1.70 \pm 0.47$ & 0.7207 \\
\hline \multicolumn{5}{|c|}{ Radiography findings } \\
\hline Cavitary lesion & $44(43.1)$ & $8(13.0)$ & & 0.0001 \\
\hline Pleural effusion & $21(20.6)$ & $10(16.1)$ & & 0.5418 \\
\hline PORT score & $89.8 \pm 35.3$ & $106.4 \pm 41.6$ & & 0.0116 \\
\hline
\end{tabular}

Data are presented as $n(\%)$ or mean $\pm S D$, unless otherwise stated; $p$-values are given for the comparison between pulmonary tuberculosis (PTB) and community-acquired pneumonia (CAP). PCT: procalcitonin; CRP: C-reactive protein; WBC: white blood cell; PORT: Pneumonia Patients Outcome Research Team.

\section{RESULTS}

\section{Patient characteristics and serum PCT levels}

102 PTB patients, 62 CAP patients, and 34 healthy volunteers were enrolled. All were seronegative for HIV. The causative micro-organism was identified in 33 CAP patients $(53.2 \%)$, with the most frequently isolated micro-organism being Streptococcus pneumoniae $(\mathrm{n}=13)$, followed by Haemophilus influenzae $(\mathrm{n}=7)$, Pseudomonas aeruginosa $(\mathrm{n}=5)$, Klebsiella pneumoniae $(\mathrm{n}=4)$, Escherichia coli $(\mathrm{n}=2)$, and Moraxella catarrhalis $(n=2)$. The characteristics of the enrolled patients are
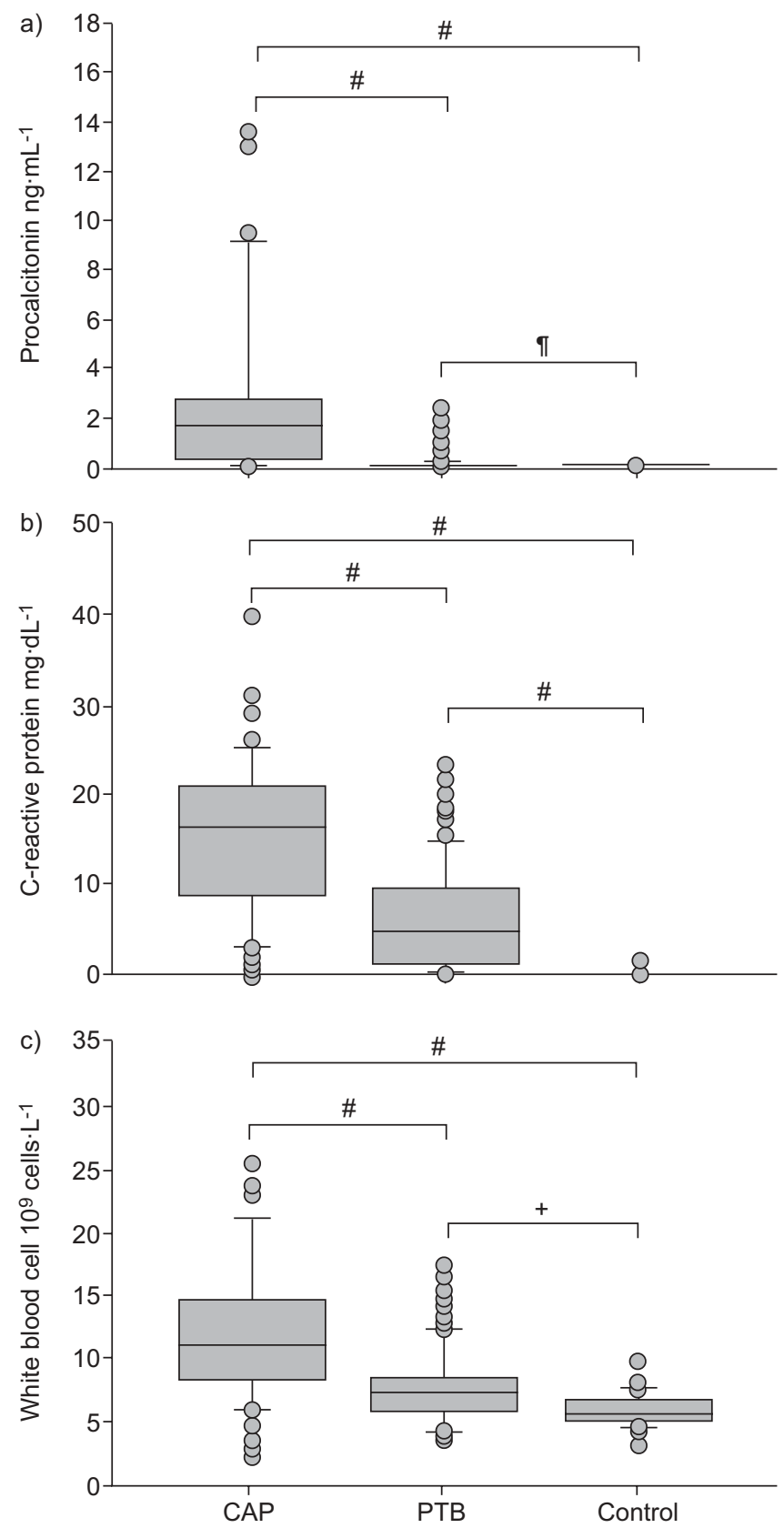

FIGURE 1. a) Serum procalcitonin, b) serum C-reactive protein and c) white blood cell count compared among pulmonary tuberculosis (PTB), communityacquired pneumonia (CAP) and healthy controls. ${ }^{*}: p<0.0001 ; ": p=0.0034$; $+: p=0.0009$ 
TABLE 2 Characteristics of disseminated tuberculosis patients and non-disseminated tuberculosis patients

\begin{tabular}{|c|c|c|c|}
\hline \multicolumn{4}{|l|}{ Demographics } \\
\hline Age yrs & $76.9 \pm 9.9$ & $70.8 \pm 19.4$ & 0.5676 \\
\hline Males/females n & $7 / 5$ & $56 / 34$ & $>0.9999$ \\
\hline \multicolumn{4}{|l|}{ Laboratory test } \\
\hline WBC $10^{9}$ cells $\cdot L^{-1}$ & $8.41 \pm 5.31$ & $7.80 \pm 3.01$ & 0.8762 \\
\hline Neutrophils $10^{9}$ cells $\cdot \mathrm{L}^{-1}$ & $7.27 \pm 3.29$ & $6.07 \pm 3.05$ & 0.1686 \\
\hline Lymphocytes $10^{9}$ cells $\cdot L^{-1}$ & $0.73 \pm 0.68$ & $1.09 \pm 0.73$ & 0.03 \\
\hline PORT score & $131.1 \pm 31.6$ & $84.5 \pm 32.2$ & 0.0001 \\
\hline Death within 60 days & $7(58.3)$ & $5(5.6)$ & $<0.0001$ \\
\hline
\end{tabular}

shown in table 1 . There were no significant differences in age $(71.5 \pm 18.5$ versus $75.2 \pm 17.0 \mathrm{yrs} ; \mathrm{p}=0.2196)$ and sex $(63 / 39$ males/females versus 38/24; $\mathrm{p}>0.9999$ ) between PTB and CAP patients. Serum PCT in PTB patients was significantly lower than in CAP patients $\left(0.21 \pm 0.49\right.$ versus $4.10 \pm 8.68 \mathrm{ng} \cdot \mathrm{mL}^{-1}$; $\mathrm{p}<0.0001$ ) (fig. 1a). PTB patients had significantly lower serum CRP and WBC count than CAP patients $(6.18 \pm 5.75$ versus $15.67 \pm 9.59 \mathrm{mg} \cdot \mathrm{dL}^{-1} ; \mathrm{p}<0.0001$ and $7.87 \pm 3.12$ versus $13.01 \pm$ $8.23 \times 10^{9}$ cells $\cdot \mathrm{L}^{-1} ; \mathrm{p}<0.0001$ ) (fig. $1 \mathrm{~b}$ and $\mathrm{c}$ ). Healthy volunteers $(11 / 23$ males/females aged $64.7 \pm 15.3 \mathrm{yrs})$ had $0.05 \pm$ $0.0 \mathrm{ng} \cdot \mathrm{mL}^{-1}$ serum PCT, $0.14 \pm 0.27 \mathrm{mg} \cdot \mathrm{dL}^{-1}$ serum CRP, and $5.95 \pm 1.33 \times 10^{9}$ cells $\cdot \mathrm{L}^{-1} \mathrm{WBC}$ count.

12 of 102 PTB patients had disseminated tuberculosis (11.8\%). As shown in table 2, disseminated tuberculosis patients had higher serum PCT $\left(0.75 \pm 0.79\right.$ versus $\left.0.14 \pm 0.39 \mathrm{ng} \cdot \mathrm{mL}^{-1} ; \mathrm{p}<0.0001\right)$ and serum CRP $\left(11.19 \pm 7.28\right.$ versus $\left.5.52 \pm 5.26 \mathrm{mg} \cdot \mathrm{dL}^{-1} ; \mathrm{p}=0.0059\right)$ than non-disseminated tuberculosis patients. The PORT score $(131.1 \pm 31.6$ versus $84.5 \pm 32.2 ; p=0.0001)$ and mortality within 60 days of admission $(58.3 \%$ versus $5.6 \% ; p<0.0001)$ were significantly higher in disseminated than non-disseminated tuberculosis patients.

\section{Discrimination between PTB and CAP}

On ROC curve analysis (fig. 2), the area under the ROC curve was 0.866 for serum PCT, 0.815 for serum CRP and 0.749 for the WBC count. Using different cut-off values, sensitivity, specificity and positive (PPV) and negative predictive values (NPV) are shown in table 3. With a cut-off value of $0.25 \mathrm{ng} \cdot \mathrm{mL}^{-1}$, serum PCT had a sensitivity of $86.3 \%$, specificity $74.2 \%$, PPV $84.6 \%$ and NPV $76.7 \%$; with a cut-off value of $10.00 \mathrm{mg} \cdot \mathrm{dL}^{-1}$, serum CRP had a sensitivity of $76.5 \%$, specificity $72.6 \%$, PPV $82.1 \%$, and NPV $65.2 \%$. Serum PCT was a better discriminative marker for PTB and CAP than the WBC count or serum CRP, but there was no significant difference among them.

\section{Prognosis}

Mortality within 60 days of admission was $11.8 \%$ (12 out of 102) in PTB patients. Two died of severe tuberculous intestinal involvement and the others of respiratory failure. All 12 patients had drug-sensitive tuberculosis. With a cut-off value of $10.00 \mathrm{mg} \cdot \mathrm{dL}^{-1}$ serum CRP, there was no significance between groups ( $p=0.1074$ ) (fig. 3a). Using a cut-off value of $0.5 \mathrm{ng} \cdot \mathrm{mL}^{-1}$ serum PCT, patients with $\geqslant 0.5 \mathrm{ng} \cdot \mathrm{mL}^{-1}$ had significantly shorter survival than those with $<0.5 \mathrm{ng} \cdot \mathrm{mL}^{-1} \quad(\mathrm{p}<0.0001)$ (fig. 3b). The characteristics of patients with PCT $\geqslant 0.5$ or $<0.5 \mathrm{ng} \cdot \mathrm{mL}^{-1}$ are shown in table 4 . A significant proportion of patients with PCT $\geqslant 0.5 \mathrm{ng} \cdot \mathrm{mL}^{-1}$ had disseminated TB compared with PCT $<0.5 \mathrm{ng} \cdot \mathrm{mL}^{-1}$ ( $55.6 \%$ versus $7.5 \%$ ).

\section{DISCUSSION}

The current study demonstrates that serum PCT in HIVnegative PTB patients is basically low and is a useful biomarker for discriminating PTB and CAP; however, when serum PCT is above the normal cut-off point $\left(0.5 \mathrm{ng} \cdot \mathrm{mL}^{-1}\right)$, it is a poor prognostic marker in PTB patients.

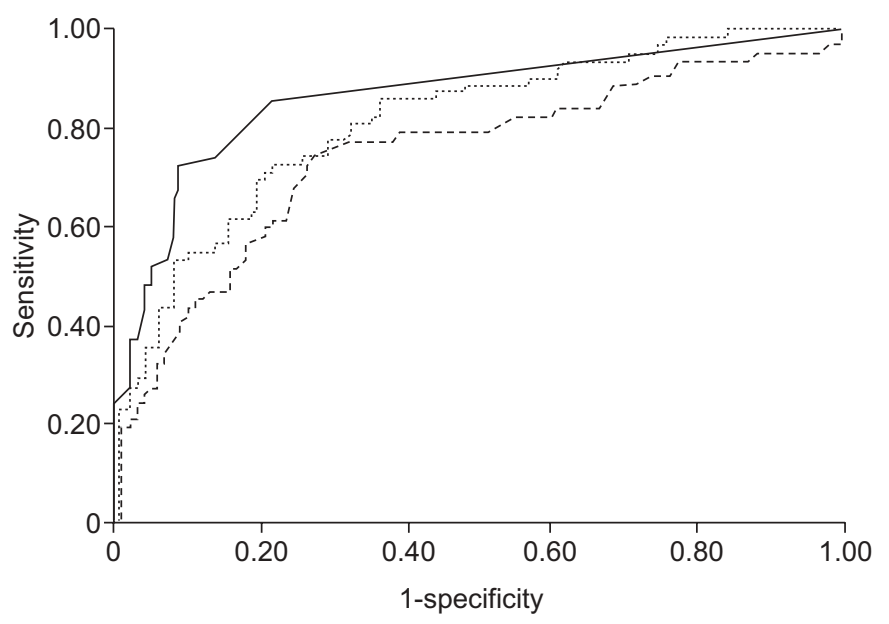

FIGURE 2. Receiver-operating characteristics curve for discrimination between pulmonary tuberculosis and community-acquired pneumonia using procalcitonin $(-)$, C-reactive protein $(\cdots \cdot)$ ) and white blood cell count $(----)$. 


\begin{tabular}{|c|c|c|c|c|}
\hline \multirow[t]{2}{*}{ TABLE 3} & \multicolumn{4}{|c|}{$\begin{array}{l}\text { Diagnostic validity of procalcitonin (PCT) and } \\
\text { C-reactive protein (CRP) in differentiating } \\
\text { pulmonary tuberculosis from community- } \\
\text { acquired pneumonia according to different } \\
\text { values }\end{array}$} \\
\hline & Sensitivity \% & Specificity \% & PPV \% & NPV \% \\
\hline \multicolumn{5}{|l|}{ РСТ $\mathbf{n g} \cdot \mathrm{mL}^{-1}$} \\
\hline$<0.1$ & 78.4 & 85.4 & 89.9 & 70.7 \\
\hline$<0.25$ & 86.3 & 74.2 & 84.6 & 76.7 \\
\hline$<0.5$ & 91.2 & 67.7 & 82.3 & 79.2 \\
\hline$<1.0$ & 92.2 & 58.0 & 78.3 & 81.8 \\
\hline$<2.0$ & 96.1 & 43.5 & 73.7 & 87.1 \\
\hline \multicolumn{5}{|l|}{ CRP $\mathrm{mg} \cdot \mathrm{dL}^{-1}$} \\
\hline$<5.0$ & 52.0 & 88.7 & 88.3 & 52.9 \\
\hline$<10.0$ & 76.5 & 72.6 & 82.1 & 65.2 \\
\hline$<12.5$ & 85.3 & 56.5 & 76.3 & 70.0 \\
\hline$<15.0$ & 90.2 & 54.8 & 76.7 & 77.2 \\
\hline$<20.0$ & 97.1 & 29.0 & 69.2 & 85.7 \\
\hline
\end{tabular}
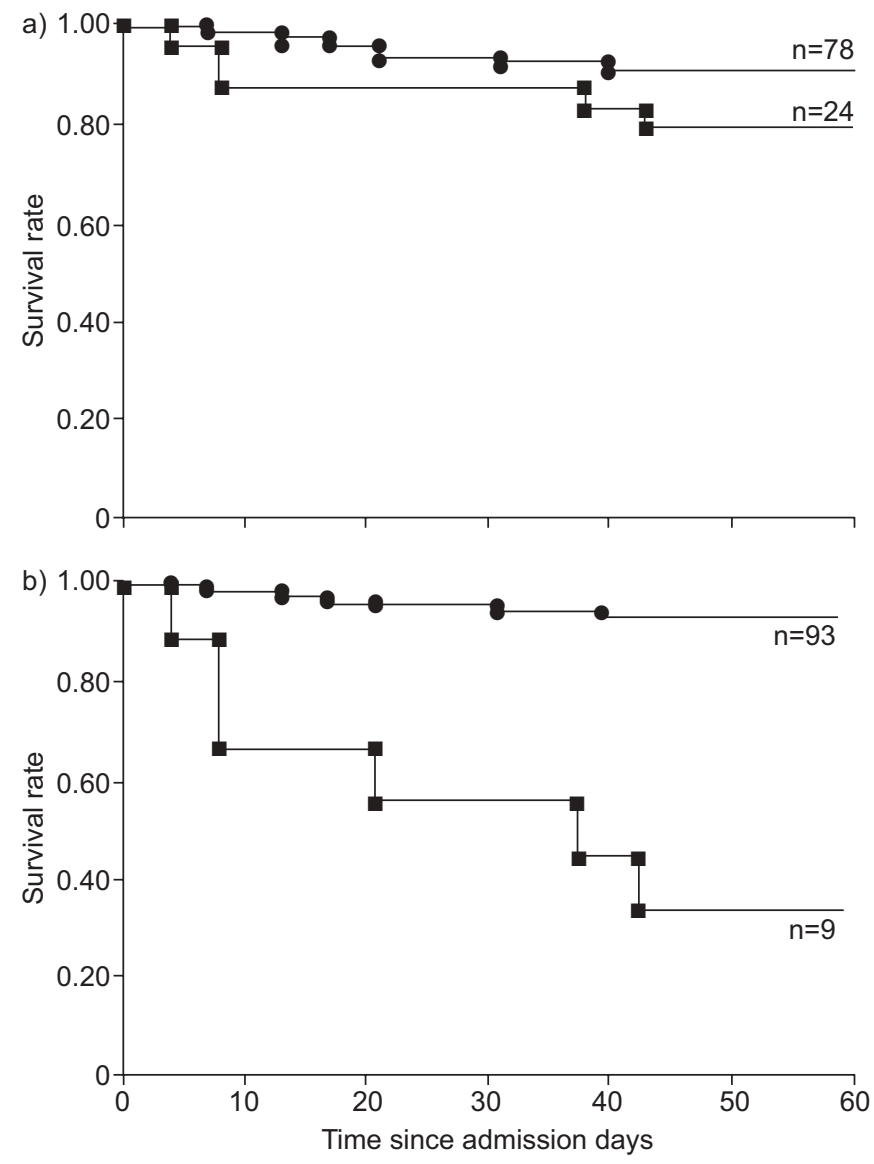

FIGURE 3. Kaplan-Meier curves for 60-day mortality with pulmonary tuberculosis patients grouped according to a) $10 \mathrm{mg} \cdot \mathrm{dL}^{-1} \mathrm{C}$-reactive protein $\left(\bullet:<10 \mathrm{mg} \cdot \mathrm{dL}^{-1}\right.$; - : $\left.\geqslant 10 \mathrm{mg} \cdot \mathrm{dL}^{-1}\right)$ and b) $0.5 \mathrm{ng} \cdot \mathrm{mL}^{-1}$ procalcitonin $\left(\bullet:<0.5 \mathrm{ng} \cdot \mathrm{mL}^{-1}\right.$; a: $\left.\geqslant 0.5 \mathrm{ng} \cdot \mathrm{mL}^{-1}\right)$.

\begin{tabular}{|c|c|c|c|c|}
\hline \multirow[t]{2}{*}{ TABLE 4} & \multicolumn{4}{|c|}{$\begin{array}{l}\text { Characteristics of pulmonary tuberculosis } \\
\text { patients with serum procalcitonin (PCT) levels } \\
\geqslant 0.5 \text { or }<0.5 \mathrm{ng} \cdot \mathrm{mL}^{-1}\end{array}$} \\
\hline & & $\begin{array}{c}\text { PCT } \\
\geqslant 0.5 \mathrm{ng} \cdot \mathrm{mL}^{-1}\end{array}$ & $\begin{array}{c}\text { PCT } \\
<0.5 \mathrm{ng} \cdot \mathrm{mL}^{-1}\end{array}$ & p-value \\
\hline \multicolumn{5}{|c|}{ Demographics } \\
\hline Patients $\mathrm{n}$ & & 9 & 93 & \\
\hline Age yrs & & $72.7 \pm 9.5$ & $71.4 \pm 19.3$ & 0.4973 \\
\hline Males/fem & es $n$ & $4 / 5$ & 59/34 & 0.2975 \\
\hline \multicolumn{5}{|c|}{ Laboratory test } \\
\hline PCT ng.m & & $1.64 \pm 0.70$ & $0.08 \pm 0.07$ & $<0.0001$ \\
\hline CRP $\mathrm{mg} \cdot \mathrm{d}$ & & $16.95 \pm 4.90$ & $5.14 \pm 4.71$ & $<0.0001$ \\
\hline WBC $10^{9}$ & $\mid s \cdot L^{-1}$ & $9.02 \pm 3.26$ & $7.76 \pm 3.11$ & 0.2451 \\
\hline Neutrophil & $10^{9}$ cells $\cdot L^{-1}$ & $8.29 \pm 3.00$ & $6.00 \pm 3.04$ & 0.0181 \\
\hline Lymphocy & $10^{9}$ cells $\cdot L^{-1}$ & $0.38 \pm 0.20$ & $1.11 \pm 0.73$ & 0.0001 \\
\hline PORT score & & $121.6 \pm 25.8$ & $86.5 \pm 34.6$ & 0.0033 \\
\hline Disseminate & tuberculosis & 5 (55.6) & 7 (7.5) & 0.0009 \\
\hline Death withir & 60 days & $6(66.7)$ & $6(6.5)$ & $<0.0001$ \\
\hline
\end{tabular}

Data are presented as mean \pm SD or $n(\%)$, unless otherwise stated. CRP: C-reactive protein; WBC: white blood cell count; PORT: Pneumonia Patients Outcome Research Team.

It has been reported that serum PCT is not elevated in PTB compared with in CAP [8-10, 17]. Although the reasons why the serum PCT response in PTB is poor remain to be clarified, there are several possible explanations. First, secreted cytokine patterns are different between tuberculous infection and common bacterial infection; for example, interferon (IFN)- $\gamma$ is a more critical cytokine for growth inhibition of mycobacteria than common bacteria [18-20]. According to in vitro observation, IFN- $\gamma$ attenuates the secretion of PCT from human adipose tissue [21]. Secondly, as previously reported, serum PCT concentration increases slightly in intracellular infection, including that caused by Mycoplasma, viruses and Pneumocystis jiroveci $[22,23]$. Since PCT synthesis and release are determined by the inflammatory cytokine cascade during systemic infection, the intensity depends on the number of organisms entering the systemic circulation. The number of organisms in PTB is probably lower than in typical bacterial pneumonia.

Conversely, NADERI et al. [24] reported that serum PCT is not a reliable marker to discriminate between РТB and non-PTB disease due to its low sensitivity and specificity; however, since the study included mild cases, such as bronchitis, and used semi-quantitative serum PCT measurement, we consider that it differed from our study.

Several studies have shown a factor related to prognosis in tuberculous patients. Regarding nutritional status, it is reported that malnutrition is a risk factor for fatality in patients with miliary tuberculosis [25], and low serum albumin levels are strongly and independently associated with death in tuberculous patients [26]. In addition to these findings, our study demonstrated that serum PCT levels over the normal cut-off point $\left(0.5 \mathrm{ng} \cdot \mathrm{mL}^{-1}\right)$ predict a poor prognosis. To our knowledge, this is the first report on serum biomarkers determining prognosis in PTB patients. 
Our study has several limitations. First, since outpatients were excluded, the enrolled patients might have had relatively severe conditions. As a result, serum PCT was elevated compared with previous studies including outpatients [1, 5]. Secondly, PTB patients could be associated with bacterial coinfection. In severe cases, we performed non-tuberculous culture of blood, urine or sputum, but pathogenic bacteria were not found. Additionally, PCT levels in PTB patients who died were significantly lower than in CAP $(0.90 \pm 0.92$ versus $\left.12.26 \pm 18.54 \mathrm{ng} \cdot \mathrm{mL}^{-1} ; \mathrm{p}=0.0073\right)$. Taken together, we do not consider that bacterial co-infection was a factor in severe PTB patients; however, we cannot completely reject the possibility of bacteria co-infection with PTB.

In conclusion, serum PCT is a better biomarker than CRP or WBC count for the differentiation between PTB and CAP in HIV-negative patients. However, it is important to realise that elevated PCT values were observed in a limited number of patients with disseminated tuberculosis, which was associated with higher mortality.

\section{STATEMENT OF INTEREST}

None declared.

\section{ACKNOWLEDGEMENTS}

We thank H. Ohta and A. Shimaya for microbiological analysis, H. Fukui, T. Sakurai, M. Uchida and M. Ogai for pleural fluid analysis, and Y. Fujisaka and N. Nakamura for data collection (Tenryu Hospital, National Hospital Organization, Hamamatsu, Japan).

\section{REFERENCES}

1 Christ-Crain M, Stolz D, Bingisser R, et al. Procalcitonin guidance of antibiotic therapy in community-acquired pneumonia: a randomized trial. Am J Respir Crit Care Med 2006; 174: 84-93.

2 Schuetz P, Christ-Crain M, Thomann R, et al. Effect of procalcitonin-based guidelines vs standard guidelines on antibiotic use in lower respiratory tract infections: the ProHOSP randomized controlled trial. JAMA 2009; 302: 1059-1066.

3 Boussekey N, Leroy O, Georges H, et al. Diagnostic and prognostic values of admission procalcitonin levels in community-acquired pneumonia in an intensive care unit. Infection 2005; 33: 257-263.

4 Masiá M, Gutiérrez F, Shum C, et al. Usefulness of procalcitonin levels in community-acquired pneumonia according to the patients outcome research team pneumonia severity index. Chest 2005; 128: 2223-2229.

5 Krüger S, Ewig S, Marre R, et al. Procalcitonin predicts patients at low risk of death from community-acquired pneumonia across all CRB-65 classes. Eur Respir J 2008; 31: 349-355.

6 Menéndez R, Cavalcanti M, Reyes S, et al. Markers of treatment failure in hospitalised community acquired pneumonia. Thorax 2008; 63: 447-452.

7 Tseng JS, Chan MC, Hsu JY, et al. Procalcitonin is a valuable prognostic marker in ARDS caused by community-acquired pneumonia. Respirology 2008; 13: 505-509.

8 Polzin A, Pletz M, Erbes R, et al. Procalcitonin as a diagnostic tool in lower respiratory tract infections and tuberculosis. Eur Respir I 2003; 21: 939-943.
9 Kang YA, Kwon SY, Yoon HI, et al. Role of C-reactive protein and procalcitonin in differentiation of tuberculosis from bacterial community acquired pneumonia. Korean J Intern Med 2009; 24: 337-342.

10 Schleicher GK, Herbert V, Brink A, et al. Procalcitonin and Creactive protein levels in HIV-positive subjects with tuberculosis and pneumonia. Eur Respir J 2005; 25: 688-692.

11 Rieder HL, Watson JM, Raviglione MC, et al. Surveillance of tuberculosis in Europe. Working Group of the World Health Organization (WHO) and the European Region of the International Union Against Tuberculosis and Lung Disease (IUATLD) for uniform reporting on tuberculosis cases. Eur Respir J 1996; 9: 1097-1104.

12 Fine MJ, Auble TE, Yealy DM, et al. A prediction rule to identify low-risk patients with community-acquired pneumonia. $N$ Engl J Med 1997; 336: 243-250.

13 Müller B, Becker KL, Schächinger $\mathrm{H}$, et al. Calcitonin precursors are reliable markers of sepsis in a medical intensive care unit. Crit Care Med 2000; 28: 977-983.

14 Harbarth S, Holeckova K, Froidevaux C, et al. Diagnostic value of procalcitonin, interleukin-6, and interleukin-8 in critically ill patients admitted with suspected sepsis. Am J Respir Crit Care Med 2001; 164: 396-402.

15 Seppä Y, Bloigu A, Honkanen PO, et al. Severity assessment of lower respiratory tract infection in elderly patients in primary care. Arch Intern Med 2001; 161: 2709-2713.

16 Chalmers JD, Singanayagam A, Hill AT. C-reactive protein is an independent predictor of severity in community-acquired pneumonia. Am J Med 2008; 121: 219-225.

17 Baylan O, Balkan A, Inal A, et al. The predictive value of serum procalcitonin levels in adult patients with active pulmonary tuberculosis. Jpn J Infect Dis 2006; 59: 164-167.

18 Schluger NW, Rom WN. The host immune response to tuberculosis. Am J Respir Crit Care Med 1998; 157: 679-691.

19 Ribera E, Ocaña I, Martinez-Vazquez JM, et al. High level of interferon gamma in tuberculous pleural effusion. Chest 1988; 93: 308-311.

20 Söderblom T, Nyberg P, Teppo AM, et al. Pleural fluid interferongamma and tumour necrosis factor-alpha in tuberculous and rheumatoid pleurisy. Eur Respir J 1996; 9: 1652-1655.

21 Linscheid P, Seboek D, Nylen ES, et al. In vitro and in vivo calcitonin I gene expression in parenchymal cells: a novel product of human adipose tissue. Endocrinology 2003; 144: 5578-5584.

22 Moulin F, Raymond J, Lorrot M, et al. Procalcitonin in children admitted to hospital with community acquired pneumonia. Arch Dis Child 2001; 84: 332-336.

23 Nyamande K, Lalloo UG. Serum procalcitonin distinguishes CAP due to bacteria, Mycobacterium tuberculosis and PJP. Int J Tuberc Lung Dis 2006; 10: 510-515.

24 Naderi M, Hashemi M, Kouhpayeh H, et al. The status of serum procalcitonin in pulmonary tuberculosis and nontuberculosis pulmonary disease. J Pak Med Assoc 2009; 59: 647-648.

25 Kim DK, Kim HJ, Kwon SY, et al. Nutritional deficit as a negative prognostic factor in patients with miliary tuberculosis. Eur Respir $J$ 2008; 32: 1031-1036.

26 Matos ED, Moreira Lemos AC. Association between serum albumin levels and in-hospital deaths due to tuberculosis. Int J Tuberc Lung Dis 2006; 10: 1360-1366. 